\author{
Alina BÂRGĂOANU* \\ Loredana RADU** \\ Elena NEGREA-BUSUIOC***
}

\title{
The Rise of Euroscepticism in Times of Crisis. Evidence from the 2008-2013 Eurobarometers
}

\begin{abstract}
The financial and economic turmoil within the European Union has significantly impacted upon the way in which the European citizens assess the advantages of EU membership and the future of the integration process. Intensely preoccupied with the economic problems, the EU leadership has lost sight of the constant decrease of public support and the increasing lack of citizens' confidence in the Union. This paper seeks to show the dynamics of public opinion between 2008 and 2013 with a special focus on the rise of Euroscepticism, using secondary data analysis of standard Eurobarometers. Our longitudinal analysis reveals the dynamics of EU-related attitudes and perceptions before, during, and after most of events that are usually labeled under the rather generic term "crisis".
\end{abstract}

Keywords: Euroscepticism; Eurozone crisis; EU legitimacy crisis; Eurobarometers.

\section{EU Public Opinion during the Crisis}

The financial and economic crisis that the European Union is currently undergoing has determined transformations both at the structural and symbolic levels of the European project. Ever since Greece's public acknowledgement of its debt-related problems in 2010 and the subsequent economic and financial problems that the country admitted it could not overcome by itself, the flawed architecture of the monetary union has been exposed and dark clouds have gathered over the EU. In spite of numerous summits, official meetings and heated debates over the austerity measures needed to overcome the negative effects of the crisis and over the solutions to save the Eurozone, consensus has not yet been reached. However, there seems to be a unanimously accepted idea among European leaders and European affairs scholars that the collapse of the European Union should be avoided (Barroso, 2011; Habermas, 2011, 2012) and that the European project should be consolidated and re-designed according to the political, economic and social realities of the global world. This urge to save the European Union is also motivated by a paradox, namely that the Union runs a major risk of disintegration precisely because it cannot disintegrate (Krastev, 2012). Given the commitment of all involved parties, in the long run, the EU will probably attain the level of political, economic and finan-

* College of Communication and PR, National University of Political Studies and Public Administration, Romania, alina.bargaoanu@comunicare.ro.

${ }^{* *}$ College of Communication and PR, National University of Political Studies and Public Administration, Romania, loredana.radu@comunicare.ro.

${ }^{* * *}$ College of Communication and PR, National University of Political Studies and Public Administration, Romania, elena.negrea@comunicare.ro. 
cial integration that it seeks, be it for the Eurozone countries only or even for Union as a whole. No matter how comprehensive this level of integration will be, there is one important aspect that the European decision-makers can hardly afford to leave unattended: the dynamics of the public opinion across the EU, its impact upon identity, citizenship, and EU-wide solidarity.

The financial and economic turmoil within the Eurozone has significantly impacted upon the way in which the European citizens assess the advantages of EU membership and the future of the integration process. Intensely preoccupied with the economic problems, the EU has lost sight of the continuous loss of public support and of the Europeans' increasing lack of confidence in the Union, as shown by Eurobarometers. The results of the spring and autumn waves of the 2010 Eurobarometer revealed an inversion of the trust-distrust ratio. In spring 2010, for the first time in the history of the European public opinion research, the distrust in the EU outweighed trust (42\% of the respondents trusted the EU, whereas $47 \%$ said they distrusted the Union). The situation persisted until the autumn 2010 wave of the Eurobarometer, although the percentages showed a slight increase of trust in the EU ( $43 \%$ of the subjects trusted the EU, whereas $45 \%$ did not). In 2013, the vivid discussions between the European Council and the European Parliament on the approval of the Multiannual Financial Framework (MFF) for the 2014 and 2020 period further affected citizens' trust in the European Union, causing a new drop in confidence: in mid-2013 only $31 \%$ of citizens from the Member States were still confident that the EU is a viable project (according to the Spring wave Eurobarometer).

However, Europeans' lack of confidence in the EU should not strike us as something new, since it is not directly or solely caused by the crisis. The financial downturn has only contributed to the increase of distrust and to the spreading of Eurosceptic attitudes. Various studies (McLaren, 2006, 2007; Leconte, 2010; Shuck and de Vreese, 2008; Radu, 2012; Negrea, 2011a, 2011b) have underscored the EU's failure to react timely to the decline of public support towards integration and the serious consequences to which this unfortunate reaction has led. The Dutch and French rejection of the Constitutional Treaty in 2005 are the most eloquent examples of a public refusal of an EU proposal. Besides, these were not singular events. In 2008, the EU was hit again by the rejection of the Lisbon Treaty by the Irish people. Such events in which people were asked for their opinion, as well as many others that followed especially during the Eurocrisis, short-circuited EU's legitimacy and strength as a supranational body.

When discussing the Eurocrisis, there is an identifiable gap in Europe between the outburst of the banking crisis, in 2008, and the crisis mananagement measures taken at EU level in 2009. This gap has proven to be very costly for the European project and has engaged the Union in a very risky process. Not surprisingly, at the end of 2008, many experts started to discuss about "Europe's crisis of leadership" or about "Europe's lack of union" in order to draw the EU officials' attention to the lack of coherence in decision-making. In 2008, two former Prime-Ministers and one European expert openly stated that "EU member states have been slow to act in concert. At first it was the European Commission that drew criticism for its slowness in making proposals to rally national governments and their policymakers. Now it is the Member States that are resisting the urgent need for a coordinated EU-wide policy response to the deepening crisis." (Amato, Davignon \& Dehaene, 2008). Thus, the so-called "global crisis" has proved to be not so global after all, and its strongest and most enduring effects have been felt at the very heart of Europe (Bârgăoanu \& Durach, 2013, p. 6).

As we will see, through their opinions, attitudes, and manifest support for the EU, the European citizens have sanctioned the decision vacuum present at the European level; for many 
of them, this decision vacuum has revealed a multi-speed Europe or an overly ambitious project but with hardly any means and no clear vision or outcome. The lack of concerted decision-making, as well as the lack of solidarity in adopting and implementing sustainable recovery measures (Dobrescu, Negrea-Busuioc \& Radu, 2013) engaged the Union in an acute legitimacy crisis.

This paper seeks to show the dynamics of EU public opinion between 2008 and 2013 (as revealed by the Eurobarometers) with a special focus on the rise of Euroscepticism. It is divided into four sections. The first section will provide a detailed presentation of various definitions of Euroscepticism; it will start with a brief incursion into the history of the term so as to then further concentrate on its evolution and development. Following Taggard's (1998) definition of Eurosceptisicm, we will examine further refinements and approaches to explain this phenomenon (Taggart and Szczerbiak, 2002; Kopecky and Mudde, 2002; Krouwel and Abts, 2007). It will also focus on the measurements of Euroscepticism and the predictors that previous research has used in order to assess manifest Eurosceptic attitudes. From Gabel's (1998) empirical test of five individual-level theories of public support of the EU, to McLaren's (2007) study of mass-level euroscepticism, and to Shuck and de Vreese (2006)'s investigation of the Dutch rejection of the Constitutional Treaty in 2005, this section will include a review of the most relevant and influent studies that have empirically tested the factors determining the formation of Eurosceptic attitudes towards the EU and the integration process.

Sections two and four will present the methodology used and discuss the results, respectively. Our analysis will show the dynamics of Eurosceptic attitudes with respect to the following predictors: the perceived democratic performance of the EU, the perceived utility of EU membership, people's feelings towards the EU and people's perception of what it feels like to belong to the EU. The last section will include the conclusions drawn from our analysis of Eurosceptic attitudes as they are revealed by Eurobarometers and will point to possible venues for future research.

\section{Euroscepticism - a Brief History of the Concept and a Review of the Accompanying Research}

From a historical point of view, the term "Euroscepticism" has not accompanied the institutional development of the European Union. The introduction of this term in the European vocabulary was favored by the notorious speech delivered by Margaret Thatcher in Bruges, in 1988, in which the British prime minister emphasized the British opposition to the idea of a European super-state headquartered in Brussels: "We have not successfully rolled back the frontiers of the state in Britain, only to see them re-imposed at a European level with a European super-state exercising a new dominance from Brussels" (Thatcher Archive, http://www.margaretthatcher.org/document/107332). Leconte (2010) considers that particular moment to comprise the essence of British opposition to the institutional and political development of the EU. The older term "anti-marketeers", which was used to express Britain's opposition to the single market, was soon replaced by the more sophisticated "Eurosceptic", which encompasses any kind of opposition to any aspect related to the European Union. Although initially considered as a phenomenon related to British politics (Harmsen \& Spiering, 2005), The popularity of Euroscepticism has grown gradually together with the EU enlargement and with the intensifica- 
tion of the integration process up to the point where it seems that the "rise of euroscepticism has become a corollary of the deepening process" (Taggart, 1998, p. 363).

Defining Euroscepticism more precisely has not proven to be an easy task. The most frequently used definition of the term express the opposition towards European integration (Taggart, 1998; Gabel, 1998; Taggart and Szczerbiak, 2002). However, this explanation whose focus is on the hostility towards integration seems to inevitably lead to a definition which narrows the meaning of the term too much. A more accurate approach to Euroscepticism would consider that the term expresses not necessarily a hostile attitude, but a spectrum of attitudes towards the EU and the integration process, ranging from distrust, cynicism, opposition to mere detachment. To comply with this broader view, Taggart (1998) proposed a definition of Euroscepticism as "a contingent or quali?ed opposition, as well as incorporating outright and unquali?ed opposition to the process of European integration" (1998, p. 366). While recognizing the merits of this definition, Kopecky and Mudde (2002) underscore some of its weaknesses. They believe that "Euroscepticism is incorrectly used with regards to parties and ideologies which are essentially pro-European, as well as to those which are openly anti-European" (2002, p. 300). The two authors' alternative to Taggart's initial view is to characterize Euroscepticism by means of analyzing different types of public support for integration. Thus, Kopecky and Mudde distinguish between "diffuse", unspecific support for "the general principles of European integration" and "specific" support for "actual integration" (2002, p. 300).

The growing literature on Euroscepticism suggests various classifications of this phenomenon. We shall briefly mention here the most influential approaches, which have also been backed up by reliable empirical research.

In their analysis of party-based Euroscepticism, Taggart and Szczerbiak (2002) have refined the definition proposed by Taggart (1998) and have described the hard and soft dimensions of the concept. The hard Euroscepticism comprises "the main opposition to the EU and the integration", while the soft Euroscepticism "expresses a qualified opposition to the EU, and the feeling that the $<<$ national interest $>>$ is not placed on the same trajectory as the development of the EU (2002, p. 7).

Empirical research has shown four factors influencing the development of Eurosceptic attitudes towards the European integration: cost-benefit analysis of EU accession and membership - the utilitarian factors, fear of the impact of the integration upon the national identity the identity factors, distrust in the supra-national institutions and the perceived threats to national sovereignty - the political factors and hostility towards the cultural and societal model of the EU - the cultural factors (Leconte, 2010; McLaren, 2004, 2006, 2007; Gabel, 1998; Gabel and Palmer, 1995). Out of these four set of factors, the utilitarian ones have been repeatedly confirmed by empirical research (Gabel (1998, McLaren 2007). Our analysis of the Eurobarometers also reveals that the Eurocrisis has prompted Europeans to reconsider their attitudes towards the EU and the integration process from a utilitarian perspective (see below).

Empirical measurements of Euroscepticism have been carried out mainly around referenda on different EU topics and around elections for the European Parliament. These are the occasions for the European citizens to make their opinions manifest and to have a say over important EU-related topics. For instance, Shuck and de Vreese (2006) examined the Dutch vote against the EU Constitutional Treaty in 2005. Furthermore, de Vreese and Tobiasen (2007) showed that the Europeans' attitudes towards the EU and their perception of the European identity influenced the results of the European elections organized in Denmark in 2004. Similar results were reported by Elgun and Tillman (2007) from a study conducted in 13 countries 
from Central and Eastern Europe. The authors showed that the negative attitudes towards others (racial, national and religious differences) are strong predictors of Euroscepticism.

De Vries and van Keerbergen (2007) identified correlations between pessimism built around the individual economic situation and exacerbated nationalistic feelings. The more economically disadvantaged an individual is, the more nationalist he/she tends to be. These findings relate to Christin and Trechsel's (2002) results linking nationalism to anti-EU attitudes (2002). We might add that there is a high probability that the current economic crisis has triggered a similar vicious circle: poor economic situation - powerful nationalistic feelings - strong anti-EU attitude. As far as the benefits from EU membership are concerned, Mahler et al. (2000) showed a strong relationship between net budgetary transfers from the EU to a member state and the level of its citizens' support for the EU.

In a 2011 study, van Spanje and de Vreese identified five predictors of the Eurosceptic vote in the 2009 parliamentary elections. By Eurosceptic vote, the authors describe the citizens' tendency to vote for members of Eurosceptic parties or for candidates who are renowned for their anti-European stance in the European Parliament. The five predictors are: 1. EU's democratic performance (the more inaccessible, opaque and undemocratic the EU and its institutions are perceived by its citizens, the more eurosceptic the latter will be), 2. negative evaluations of EU membership (the more negatively people evaluate EU membership, the higher the probability for a Eurosceptic vote), 3. negative feelings towards the EU (the more negative citizens' feelings towards the EU, the higher the probability for a Eurosceptic vote), 4. opposition to EU enlargement (the more inclined are the citizens to oppose the European integration, the higher the probability for a Eurosceptic vote), and 5. lack of European identity (the more inclined are the citizens to identify themselves with the EU, the higher the probability that they vote for a pro-European politician). The two authors established correlations between the EU's legitimacy deficit and Euroscepticism. According to them, the EU perceived legitimacy has the following key components: trust in the EU's institutions, people's capacity to identify with the European project and their trust in the European decision-making process. In our analysis, we have used four of de van Spanje and de Vreese's predictors to re-interpret the data from Eurobarometers. We have found that the EU's legitimacy crisis is linked to public perceptions of the EU's trustworthiness and with the rise of Eurosceptic attitudes towards the European integration.

\section{Data and Methodology}

We have used secondary quantitative data analysis to investigate patterns of public Euroscepticism from 2008 to 2013. The Eurosceptic attitudes of various actors, such as elites, parties, experts, business leaders or mass media are not explored in this study and will be an object of further investigation.

We have based our empirical analysis on standard Eurobarometer (EB) surveys publicly available on the website of the Public Opinion Analysis sector of the European Commission. The data set which our study focused on consisted of the following standard EBs: EB 69 (Spring 2008), EB 70 (Autumn 2008), EB 71 (Spring 2009), EB 72 (Autumn 2009), EB 73 (Spring 2010), EB 74 (Autumn 2010), EB 75 (Spring 2011), EB 76 (Autumn 2011), EB 77 (Spring 2012), EB 78 (Autumn 2012), and EB 79 (Spring 2013). Our choice of this methodology was motivated by the advantages of secondary data analysis, such as economy in terms 
of time and costs of data collection or the breadth of data available (Boslaugh, 2007), and by the fact that this method of inquiry allows the researcher "to study specific problems by means of examining data that was originally collected for other purposes" (Smith, 2006, p. 3). In the standard EB, there is no question that directly addresses the issue of Euroscepticism (Gabel, 1998; McLaren, 2006); however, one can analyze several EB standard questions regarding people's level of trust in the EU or the EU's institutions, their assessment of the performance of the EU, their optimistic or pessimistic attitudes towards the future of the EU, and link the answers to these questions to evolution trends of Eurosceptic attitudes across a given period of time.

In our study, we have re-analyzed data from the abovementioned EBs in order to compare the manifest public opinions of citizens of Eurozone countries and those of citizens of non-Eurozone countries against the EU average. To this purpose, we have adapted and replicated a recent research by van Spanje and de Vreese (2011) in which they assessed the motivations underlying the 2009 Eurosceptic vote. We have used only three out of the five predictors of Euroscepticism identified by the two authors, namely EU's democratic performance, public assessment of the utility of EU membership, and the presence of negative feelings towards the EU.

\section{Findings}

News on Greece's huge public debt spread all over Europe in spring 2010. That moment also marked the beginning of a gradual decline of public support for the Union. Public opinion surveys recorded the discontent of the citizens in Eurozone countries with EU's democratic performance, decision-making and crisis management capacity. Between 2008 and 2013, people became more and more dissatisfied with the way in which democracy works in the EU, as their level of satisfaction decreased from $52 \%$ in 2008 to $43 \%$ in 2013 .

Figure 1. Level of Europeans' satisfaction regarding the functioning of democracy in the EU.

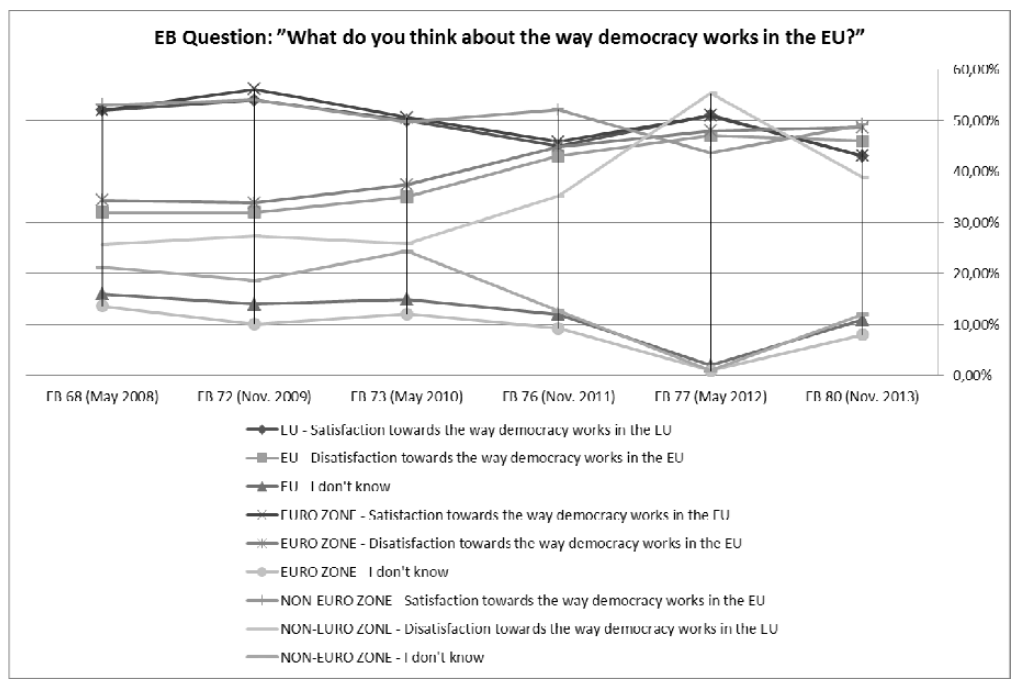


Right before the outburst of the crisis, statistics showed no significant changes among the Euro zone and the non-Euro zone countries as regards EU's democratic performance. In 2008, $53 \%$ of the citizens in the Eurozone countries and $52 \%$ of the citizens in the non-Eurozone countries declared themselves satisfied with the European democratic functioning. The beginning of 2011 witnessed an important change in the way in which European citizens perceive the functioning of democracy in the EU. The sudden fall in the level of satisfaction was mainly triggered by the Euro-zone countries, which, starting from 2011, became more skeptical with regard to the level of democracy within the EU than their fellow non-Eurozone countries. As the Figure 1 shows, the latter became slightly more optimistic towards the functioning of democratic mechanisms in Brussles than they were in the autumn of 2010. We may explain these statistically documented trends by referring to the "Greek question", which became the central crisis-related event in 2011 and posed the much-acclaimed European solidarity under a question mark. The Greek crisis turned into the epicenter of the "Euro crisis", being subjected to many controversies and dividing the public opinion between supporters and opponents of the bail-out to be offered by the European Commission and the International Monetary Fund in order to avoid Greece's bankruptcy. Between 2010 and the start of 2012, Greece was the recipient of aprox. 400 billion Euro, this being considered as "the most expensive bail-out in the history of the European Union." (Radu, 2012, p. 62). In our view, there was an additional factor that caused a lot of fuss among citizens of the Member States: the austerity measures that have been implemented in most Member States since 2010. The frustration caused by this belt-tightening exercise, as well as the negative perceptions around the massive capital injection in the "dishonest Greece", gave birth to a wave of skepticism among the crisis-hit Eurozone countries, such as Spain, Portugal, Italy, and Ireland that saw themselves as potential candidates to bankruptcy.

We could notice that the indicator "Eurozone - satisfaction with the functioning of the democracy in the EU" registered higher values in the countries whose economies are healthier, such as Austria (67\%), Belgium (68\%), Finland (77\%), France (67\%), Germany (70\%), Luxembourg (84\%) and the Netherlands (78\%). Conversely, citizens from those countries that face a very difficult economic situation, such as Greece or Portugal, tend to believe that the European democracy is not a very feasible construct. For example, as compared to the economically healthier countries mentioned above, only $22 \%$ of the Greeks and $16 \%$ of the Portuguese think that democracy works well in the EU. This is supportive of the idea that there is a link between the economic performance of an EU member state (output-based legitimacy) and people's perception of the functioning of democracy within the EU (input-based legitimacy). We can infer from this that a poor economic performance of their country might trigger citizens' scepticism and distrust towards EU functioning overall, including its democratic functioning. This finding adds evidence to the general cost-benefit framework in which people tend to analyze the perceived advantages of European integration. It empirically confirms Habermas' observation that, "for a considerable period of time, The Union has legitimized itself in the eyes of the citizens primarily through its outcomes and not so much by the fact that it fulfilled the citizens' political will" (Habermas, 2013). Now that output-based legitimacy is under a cloud due to the economic crisis, questions of input-legitimacy are also put forth, emphasizing "the a gulf at the European level between the citizens' opinion and will formation, on the one hand, and the policies actually adopted to solve the pressing problems, on the other" (Habermas, 2013). 
Coming back to the results displayed by Eurobarometers, there is a significant drop in the way in which citizens from non-Euro zone countries assess EU democratic performance. In $2008,25 \%$ of the respondents in the non-Euro zone countries were dissatisfied with the way in which democracy works in the EU, whereas in 2013 the level of dissatisfaction rose to almost $39 \%$. Poland - a country that, out of EU member states, was the least affected by the economic crisis - is the most satisfied with the European democracy, almost $70 \%$ of its citizens perceiving the EU democracy as solid. This further confirms that there is a link between the economic performance at the national level and people's perception of the functioning of the EU democracy.

Another important indicator of the performance of democratic mechanisms within the EU is the perception regarding public participation and involvement in the decision-making process in Brussels. Thus, in our study, we have found that between 2011 and 2012 citizens of Eurozone and non-Eurozone countries, respectively, differ in the perception of the importance of their voice within the EU, as shown in Figure 2.

Figure 2. Citizens' perceived importance of their voice in the EU.

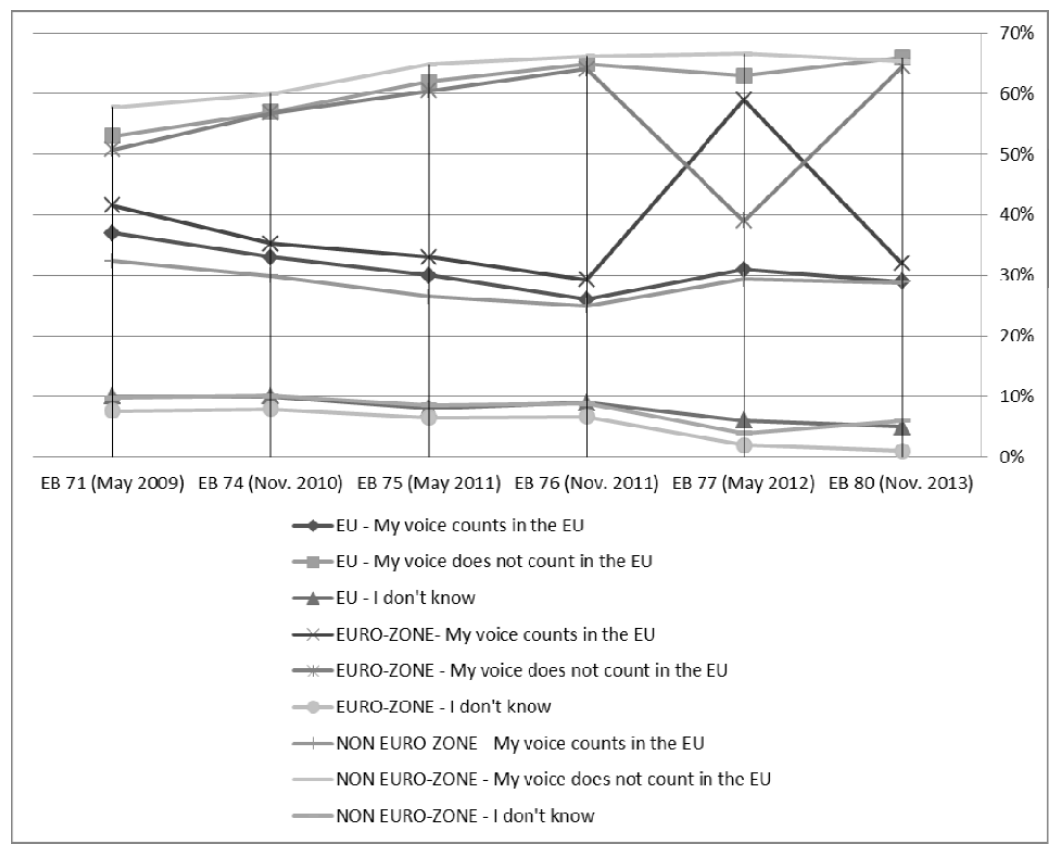

The autumn 2011 EB shows relatively homogenous opinions held by Europeans with regards to this indicator - the importance of their voice in the EU. However, the 2012 spring survey registered a significant gap between the values of this indicator for Eurozone and nonEurozone population, respectively. This trend is more clearly noticeable in the case of the member states that have tried to lower their budgetary deficits by contracting external loans and by enforcing austerity measures. For instance, in spring 2012, only $25 \%$ of the Bulgarians, $21 \%$ of the Romanians and $17 \%$ of the Czechs still believed that their voice was heard in Brussels. At the same time, the value of the indicator "Eurozone - my voice is important in the EU" increased due to the radical change of opinion among the French $(47 \%$ of them think that their voice is important in the EU), the Germans ( $40 \%$ think that their voice is im- 
portant) and the Dutch (50\% stated that their voice is important in the EU). Germany, Netherlands, and France are among those countries that played a major role in designing the crisismanagement measures. This is why the French president and the German chancellor were labeled by mass-media as "European leaders" (Radu, 2012) in what concerns the critical decisions revolving around the current crisis. Our finding is supportive of the idea that there is a relation between the political involvement of national states in EU policy-making, on the one hand, and the citizens' perceived importance of their voice in the EU, on the other. If member states act prominently on the European scene, their citizens are more likely to feel involved in and heard by the European Union. Consequently, those member states that are not strongly positioned in European decision-making tend to transfer this lack of power at the level of their citizens, who feel that their "voice" means nothing for the EU.

If we look at the degree to which Europeans understand the functioning of the EU in the context of the current economic crisis, it seems that citizens have arrived at a better knowledge of the EU institutions and of European officials' activity within the EU. Thus, the higher level of Europeans' knowledge of the way in which the EU functions shows that the difficulties generated by the crisis have motivated the citizens to seek more information on the institutional and decision-making mechanisms that affect them either directly or indirectly. Statistics show that the crisis has driven many people to get more informed about the EU, which has implicitly led to a rise in demand of EU-related information. Of course, there are exceptions in this regard. In 2012, Estonians stated that they knew as little about the EU as they had known before the crisis hit Europe; only 33\% of them said that they had solid knowledge about the EU. Similarly, only $35 \%$ of Italians said that they knew how the EU functioned. In spite of these special cases, it appears that the current crisis gave rise to many question marks that the citizens of the member states wanted to answer by looking more attentively at the EU.

Furthermore, if we look at both the indicator measuring the level of EU-related knowledge, on the one hand, and at the one which measuring the way in which people assess the costs and benefits of the EU membership, on the other, we can see that the crisis has triggered an erosion of the credibility of the status of being a EU member state, and that the general trend is to deny the advantages that follow from the EU membership. In a nutshell, even though citizens of the member states have become more informed about the EU and its mechanisms, their assessment of the advantages deriving from their countries' membership has worsened. We could rightfully state that, under the pressure of the crisis, many Europeans have started to make educated evaluations regarding the cost-benefit ratio associated with the EU and their specific countries. At the end of 2010, when the crisis was fully present all across Europe, the EB showed a rise in the number of non-Eurozone citizens who said that EU membership brought no solid benefits. In 2009 , over $60 \%$ of the non-Eurozone citizens considered that their countries benefitted significantly from EU membership; by the end of 2012, only $49 \%$ of them maintained this opinion. Additionally, we have noticed a significant increase of the "don't know/ don't answer" category, from 4\% in 2009 to 16\% in 2012 among the citizens of non-Eurozone countries. Furthermore, the citizens of non-Eurozone countries that entered the EU during the last two enlargement waves have become more undecided with regard to the cost/benefit ratio of EU membership. Noteworthy, the standard EBs from 2013 did not include a separate question regarding the benefits arising from EU membership, which might indicate a possible concern in Brussels with the drastic drop of the number of Europeans still 
assessing their country's membership in a positive manner. In the $2013 \mathrm{~EB}$, such a question was addressed only to people from Turkey and Island.

According to van Spanje and de Vries (2011), citizens' level of trust in the EU is the third predictor of Euroscepticism. The analysis of the public trust in the EU and its institutions provides insightful information on the aggravation of the EU's legitimacy crisis under the pressure of the economic crisis. The EBs between 2008 and 2013 show a significant decrease of public trust in the EU (see Figure 3 below), the European Council, the European Commission, or the European Central Bank. To put it more drastically, European citizens have withdrawn the confidence which they previously invested in the EU and its institutions. The poor reaction of EU's institutions to the crisis did not go unnoticed by the Europeans. Currently, almost $60 \%$ of the people who filled in the EB questionnaires have said that they did not trust the EU anymore. Lack of confidence is a generalized phenomenon among the European citizens who tend to deny or reject the majority of EU-related issues.

Figure 3. Europeans' trust in the EU

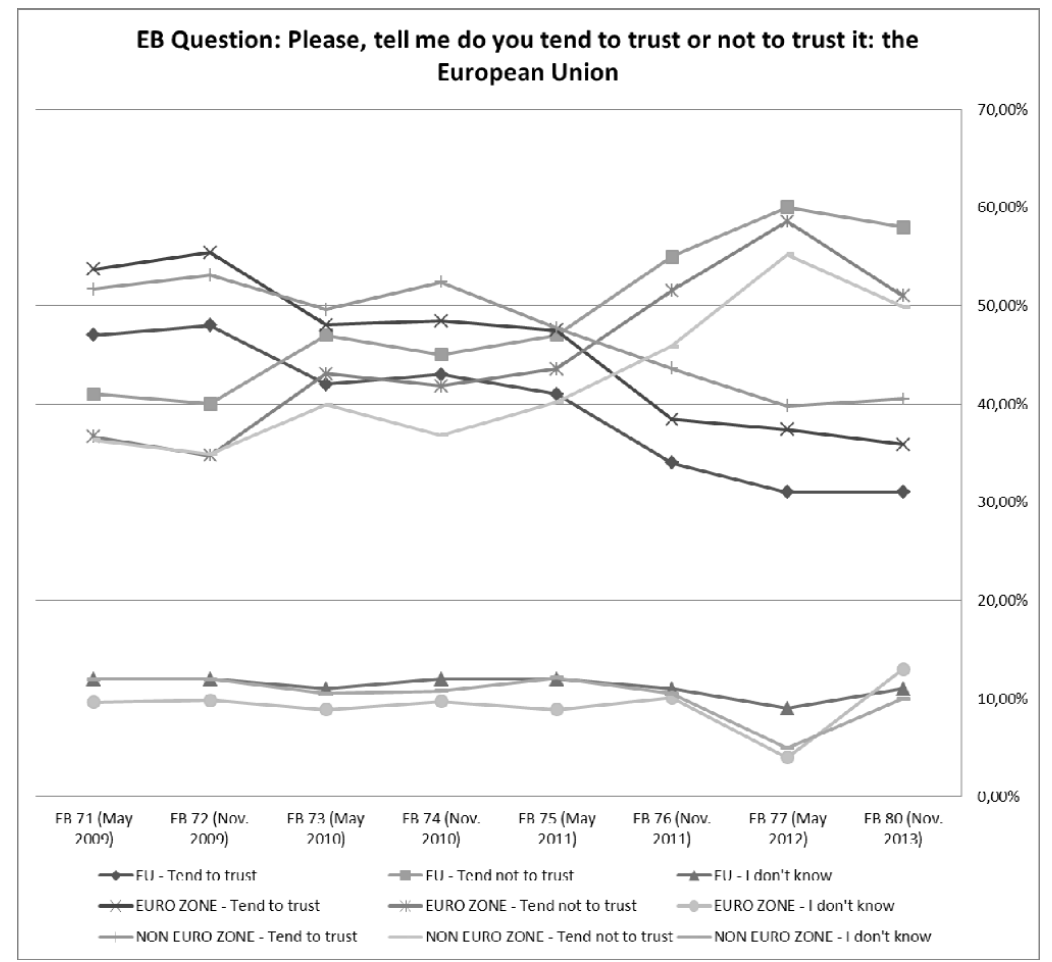

The decrease of Europeans' trust in the EU is mostly visible in the autumn 2012. During 2010 and 2011, many member states had to implement austerity measures over a short period of time and in a quite aggressive manner. The Greek crisis generated heated debates and many controversies, which ultimately split the European public opinion between the supporters of the plans to save Greece, on the one hand, and those unwilling to pay for Greece's debts, on the other.

Non-Eurozone countries have actually experienced the economic crisis more intensely than their fellow Eurozone countries. The majority of the countries outside the Eurozone are 
emerging economies which have been deprived of their most important source of growth foreign investments -, and which struggle hard with public deficits and inflation. This might be an explanation for the sudden decrease of non-Eurozone citizens' trust in the EU.

One important indicator measuring the level of citizens' trust in the EU is the manner in which they evaluate the future of the EU. This indicator helps us quantify whether Europeans perceive the current situation in the EU as a permanent one, thus unlikely to improve, or as temporary or transitory one, that will eventually improve. People's confidence in a better future is an essential aspect that is used on behavioral economics in order to forecast consumption behavior and economic well-being. According to behavioral economists, if people are positive regarding the future of their own countries, then the state of the economy will improve. Keeping in mind this assumption, we could infer that if Europeans are confident that the EU has a bright future, then it is more probable that the situation in the EU will have a positive outcome.

The year 2009 registered a shift from optimism to pessimism towards the future of the EU (Figure 4). Europeans became more pessimistic towards the future of the European integration, though in 2013 there are some timid signs of a newly found optimism.

Figure 4. Optimism/pessimism towards the future of the EU

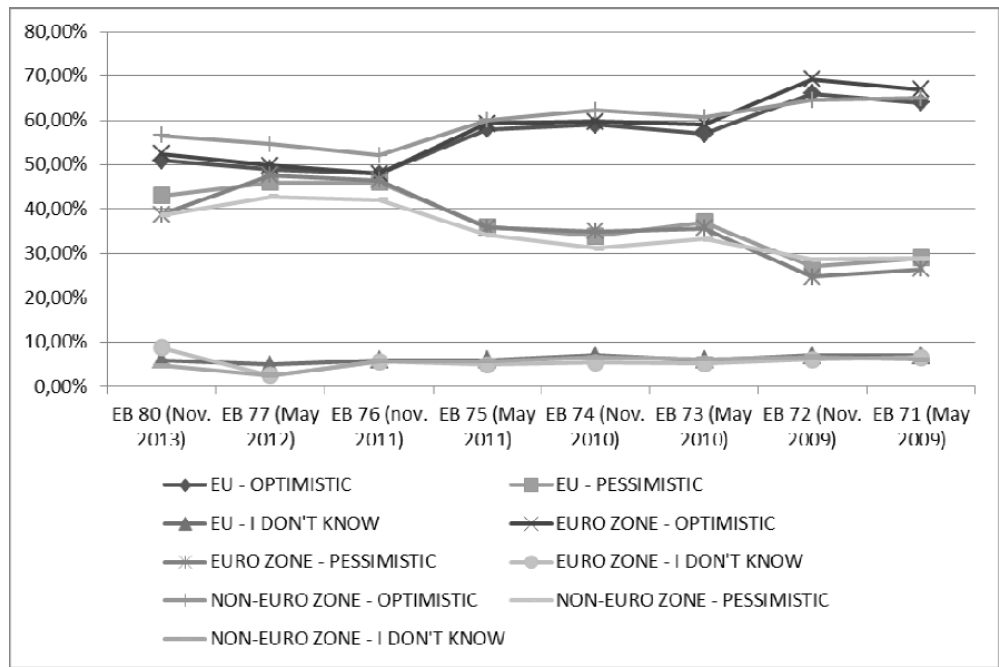

The rise of pessimistic attitudes developed in two phases. The first signs of rising pessimistic attitudes were registered in spring 2010 and it is possible that this was caused by the contradiction between the EU officials' discourse on the end of the recession, on the one hand, and the visible socio-economic reality, on the other hand. The unemployment rate (EU overall, but especially in the South) increased continuously between 2010 and 2011; moreover, the public debt of national governments grew significantly, which led to the implementation of austerity measures both in Eurozone and non-Eurozone countries. All these facts contributed to the rise of Europeans' pessimism towards the future of the European project. Furthermore, in 2011, the Europeans witnessed the collapse of the Greek economy and the street protests organized by the Greek citizens, who felt suffocated by the constant request that they "tighten the belt". The two 2011 EBs show that these social and political events were extremely detrimental to the EU in terms of people's trust. 
Europeans' trust in EU institutions has dropped gradually after the outburst of the economic crisis. This tendency is visible both in the Euro-enthusiastic countries (at least before the crisis hit the EU), such as Estonia, the Czech Republic, Romania, Bulgaria, Hungary, etc., and in the "traditional" Eurosceptic countries, such as UK, Denmark or Sweden. We can conclude that, under the pressure of the problems triggered by the economic crisis, the Europhile countries have lost their confidence in the EU, whereas the already low level of trust of the Eurosceptic countries has registered even lower values.

Standard EBs reveal that the European Council has undergone a crisis of confidence similar to the lack of trust in the EU. In the aftermath of the Greek crisis in 2010, the decrease of trust in the Council is visible both in the Eurozone and non-Eurozone countries. Through its leader, Herman van Rompuy, the European Council has aspired to be a "crisis cell" which coordinates all legislative measures designed to help overcome the crisis. As the EBs show, it seems that the initiatives of the European Council did not meet the public's expectations, hence the Europeans' lack of confidence in this institution.

According to Eurobarometers, the European Commission is the most visible European institution. In spite of its notoriety, it is also confronted with a serious lack of trust. If in 2008, only $23 \%$ of the respondents said that they didn't trust the European Commission, in autumn 2011 the percentage was almost double. At the end of 2013, 47\% of respondents stated that they tended not to trust this institution. As regards the European Parliament, the numbers are quite similar, showing that currently only $39 \%$ of the citizens in the Member-States have confidence in it.

\section{Conclusions. Europeans - United by Euroscepticism?}

By using van Spanje's and de Vreese's predictors of Euroscepticism (2011), our analysis has sought to back up the statement according to which EU is confronted with an acute legitimacy crisis (both input- and output-based), which relates to the strengthening of Eurosceptic attitudes. Europeans' trust in the future of the EU, in its democratic and economic performance has registered a continuous decline. The austerity measures implemented in 2010 have amplified this constant trend. The partial recovery of European GDP at the end of 2011 has not significantly contributed to a revival of people's trust in the EU and its institutions, which demonstrates the gap between the reality presented by the economic indicators and the reality experienced by the citizens of the member states.

In 2012, two new trends emerged. First, the EU newcomers (from the 2004 and the 2007 enlargement waves), previously known as Euroenthusiasts, have developed Eurosceptic attitudes. Their drastic withdrawal of trust after 2009 is mainly indicative of the fact that their expectations have not been met ever since the accession and the way in which the EU responded to the crisis provided the perfect channel for expressing that post - EU accession syndrome. Second, the "usual" Eurosceptic countries (Austria, France, the Scandinavian countries) seem to experiment a complex phenomenon which can be described as a combination between Eurosceptic attitudes towards the European institutions and optimistic attitudes towards the way in which their voice and interests are heard in Brussels. This is emblematic for how powerful economies position themselves in relation to key European decisions.

Our research has provided enough evidence that, nowadays, the European Union has to deal with two crises, at least. One is the already well-known economic crisis, which the EU 
has been struggling to address through a series of complex measures. The other is a legitimacy crisis for which the EU has not developed a proper strategy so far. The economic crisis has exposed Europe's legitimacy crisis; conversely, the Europe's legitimacy crisis is at the heart of the Europe's recovery plan.

What appears to be certain is that the balance between Euroenthusiasts and Eurosceptics has been inclined in favor of the former. Euroscepticism relates to feelings of uncertainty, which, in turn, give birth to people's natural desire to step back to their own comfort zone. Depending on many variables, such as the economic context and the way in which the EU is positioned on the public agenda, this comfort zone may be the national arenas or may generate (Euro-)apathy. Alternately, it might stimulate a constructive debate regarding what improvements need to be done for the European project to survive. As long as the European institutions do not capitalize on Euroceptic attitudes and the newly found public interest in the European Union, extremisms, populisms and apathy seem to be the most likely effects of public attitudes towards the EU. This becomes particularly relevant in the eve of the European elections, when voters will most likely remain in their comfort zone and, thus, will show either stick to their national arenas or show apathy.

The analysis of the 2008-2013 Eurobarometers shows that the rise of Euroscepticism is a complex and ample phenomenon within the EU. Complex and ample as it may be, it is also heterogeneous and, according to Habermas (2013), "what unites European citizens today is the Eurosceptic mindset that has become more pronounced in all of the member countries during the crisis, albeit in each country for different and rather polarizing reasons".

Ironically enough, the reasons for Euroscepticism across Europe, whether we are talking about party-based Euroscepticism or public Euroscepticism, vary more or less depending on the interests of the member state and its location on the EU map. Eurosceptics in the North no longer want to pay for Europe's Southern periphery and, in line with the above-mentioned speech of Margaret Thatcher, cry loudly "I want my money back"; Eurosceptics in the South cry equally loudly "I want my jobs back". The Central and Eastern Europe suffers from a postEU accession syndrome and is caught in a complex game characterized by a lack of geopolitical and economical alternatives; which does not stop the Eurosceptics from this other periphery of the European Union to cry loudly "I want my expectations back". This heterogeneity prevents public Euroscepticism from becoming a political force across Europe and finding its expression in a European-wide project.

\section{References}

1. Amato, G., Davignon, E., \& Dehaene, J-L. (2008). Europe's Crisis of Leadership, [online] Available at http://www.project-syndicate.org/commentary/europe-s-crisis-of-leadership [Accessed 16 October 2012].

2. Barroso, J. M. (2011). European renewal - State of the Union Address 2011. [online] European Parliament, Strasbourg, 23 September 2011. Available at:<http://ec.europa.eu/commission_2010-2014/president/state-union-2011/index_en.htm $>$ [Accessed 15 October 2012].

3. Bârgăoanu, A., \& Durach, F. (2013). The Crisis of the European Union and its Reflection in the Romanian Public Sphere. Recent Findings. Romanian Journal of European Affairs, vol. 13, no. 1, 5-24.

4. Boslaugh, S. (2007). Secondary Data Sources for Public Health: A Practical Guide. Cambridge: Cambridge University Press. 
5. Christin, T., \& Trechsel, A. (2002). Joining the EU ? Explaining public opinion in Switzerland. European Union Politics, 3 (4), 415-443.

6. de Vreese, C., \& Tobiasen, M. (2007). Conflict and identity. Explaining turnout and anti-integrationist voting in the Danish 2004 elections for the European Parliament. Scandinavian Political Studies, 30, $87-111$.

7. de Vries, C., \& van Keerbergen, K. (2007). Interest, Identity, and Political Allegiance in the European Union. Acta Politica 42(2), 307-328.

8. Dobrescu, P., Negrea-Busuioc, E., \& Radu, L. (2013). Requiem of Solidarity. An Analysis of the European Discourse on the 2014-2020 Multiannual Financial Framework. Romanian Journal of Communication and Public Relations. Vol. 15 No. 1 (28), 75-90.

9. Elgun, O., \& Tillman, E. (2007). Exposure to European Union policies and support for membership in the candidate countries. Political Research Quarterly, 60(3), 391-400.

10. Gabel, M. (1998). Public Support for European Integration: An Empirical Test of Five Theories. The Journal of Politics, 60 (2), 333-354.

11. Gabel, M., \& Palmer, H. D. (1995). Understanding variation in public support for European integration. European Journal of Political Research, 27, 3-19.

12. Gros, D. (2009). The Dogs That Didn't Bark: The EU and the Financial Crisis. Current History, 105-109.

13. Habermas, J. (2011). A pact for or against Europe? In: U. Guérot and J. Hénard (eds.) What does Germany think about Europe? (pp. 83-89). London: ECFR.

14. Habermas, J. (2012). For a more democratic Europe. [online] Available at http://www.greeneuropeanjournal.eu/for-a-more-democratic-europe. Accessed March 16, 2013.

15. Habermas, J. (2013). Democracy, Solidarity And The European Crisis. Social Europe Journal, [online] Available at http://www.social-europe.eu/2013/05/democracy-solidarity-and-the-european-crisis-2/. Accessed March 20, 2013.

16. Harmsen, R., \& Spiering, M. (2005). Euroscepticism: Party Politics, National Identity and European Integration. Amsterdam: Rodopi.

17. Kopecky, P., \& Mudde, C. (2002). The Two Sides of Euroscepticism. Party Positions on European Integration in East Central Europe. European Union Politics, 3 (3), 297-326.

18. Krastev, I. (2012). The European dis-union. Lessons from the Soviet collapse. [online] Eurozine. Available at: $<$ http://www.eurozine.com/articles/2012-07-26-krastev-en.html $>$ [Accessed 19 November 2012].

19. Krouwel, A., \& Abts, K. (2007). Varieties of Euroscepticism and Populist Mobilization: Transforming Attitudes from Mild Euroscepticism to Harsh Eurocynicism. Acta Politica, 42, 252-270.

20. Leconte, C., 2011. Debunking myths about Euroscepticism. [online]. Social Europe Journal. Available at: < http://www.social-europe.eu/2011/11/debunking-myths-about-euroscepticism/> [Accessed November 2012].

21. Leconte, C., 2010. Understanding Euroscepticism. NY: Palgrave Macmillan.

22. Mahler, V., Bruce, J.T., \& Wozniak, J. (2000). Economics and public support for the European Union: an analysis at the national, regional and individual levels. Polity, 32 (3), 429-453.

23. McLaren, L.M. (2007). Explaining Mass-Level Euroscepticism: Identity, Interests, and Institutional Distrust. Acta Politica, 42, 233-251.

24. McLaren, L.M. (2006). Identity, Interests and Attitudes to European Integration. NY: Palgrave Macmillian.

25. McLaren, L.M. (2004). Opposition to European integration and fear of loss of national identity: Debunking a basic assumption regarding hostility to the integration project. European Journal of Political Research, 43, 895-911.

26. Negrea, E. (2011a). The making of European identity: the EC President's 2011 address to the European Parliament. Romanian Journal of Communication and Public Relations, 13, 4 (24) 49-59.

27. Negrea, E. (2011b). Tendinte ale euroscepticismului in Romania. Observatii pe marginea rezultatelor unui sondaj national. In A. Bârgăoanu and E. Negrea (eds.) Comunicarea in Uniunea Europeana. Modele teoretice si aspect practice. (pp. 167-186). Bucharest: communicare.ro. 
28. Radu, L. (2012). Criza economica in Uniunea Europeana. O perspective comunicationala. Bucuresti: comunicare.ro.

29. Secchi, C. (2012). More leadership for more Europe. [online] Project Syndicate. Available at: $<$ http://www.project-syndicate.org/commentary/the-eurozone-s-leadership-crisis-by-carlo-secchi> $>$ Accessed 20 November 2012].

30. Shuck, R.T., \& de Vreese, C. (2006). Between risk and opportunity. : news framing and its effects on public support for EU enlargement. European Journal of Communication, 21 (5), 5-32.

31. Smith, E. (2006). Using Secondary Data in Educational and Social Research. Berkshire: Open University Press.

32. Stratulat, C., \& Emmanouilidis, J.A. (2013). The European Parliament elections 2014 Watershed or, again, washed out? European Policy Center. Retrieved from http://www.epc.eu/pub_details.php?pub id=3699 on May 72014.

33. Taggart, P. (1998). A touchstone of dissent: Euroscepticism in contemporary Western European party systems. European Journal of Political Research, 33, 363-388.

34. Taggart, P., \& Szczerbiak, A. (2008). Introduction: Opposing Europe? The Politics of Euroscepticism in Europe. In A. Szczerbiak and P.Taggart (eds.) Opposing Europe? The Comparative Party Politics of Euroscepticism, (pp. 1-15.), Volume 1, Case Studies and Country Surveys. Oxford: Oxford University Press.

35. Taggart, P., \& Szczerbiak, A. (2002). The Party Politics of Euroscepticism in EU Member and Candidate States. SEI Working Paper No 51 and Opposing Europe Research Network Working Paper No 6, Sussex European Institute. Available at: < http://www.sussex.ac.uk/sei/documents/wp51.pdf $>$ [Accessed June 2012].

36. Torreblanca, J. I. (2011). Democracy put to the test. [online] Eurozine. Available at: $<$ http://www.eur ozine.com/articles/2011-12-01-torreblanca-en.html> [Accessed 19 November 2012].

37. Van Spanje, J., \& de Vreese, C. (2011). So what's wrong with the EU? Motivations underlying the Eursceptic vote in the 2009 European elections. European Union Politics 12, 405-428.

38. ${ }^{* * \star}$ Speech to the College of Europe, 1988 (“The Bruges Speech”), Thatcher Archive, http://www.margaretthatcher.org/document/107332. Accessed January 17, 2013. 